\title{
EFFECT OF FENNEL WATER EXTRACTS ON REDUCTION OF FEEDING OF PEA LEAF WEEVIL
}

\author{
Barbara Biniaś', Janina Gospodarek', Milena Rusin' \\ 1 Department of Agricultural Environment Protection, University of Agriculture in Krakow Al. Mickiewicza 21, \\ 31-120 Krakow, e-mail: binias.barbara@gmail.com, rrjgospo@cyf-kr.edu.pl, milena_rusin@wp.pl
}

Received: 2016.08.01 Accepted: 2016.09.26 Published: 2016.11.01

\begin{abstract}
The objective of the study was to examine the effect of aqueous extracts from fennel (Foeniculum vulgare Mill.) seeds at 2\%,5\%,10\% and 20\% concentrations on the feeding of peal leaf weevil (Sitona lineatus L.) on broad bean (Vicia faba L.). The experiment was conducted in the laboratory, in six replicates. Feeding intensity assessment was conducted by dipping leaves of broad bean in respective solutions of the extracts and determining the area of broad bean leaves, eaten by pea leaf weevil beetle in 12 hour intervals. In addition, absolute deterrence index and palatability index were calculated. As a result of the observation no significant limiting effect of fennel seed aqueous extracts on the feeding of the pea leaf weevil females was shown. All of the used fennel extracts had inhibitory effect on the feeding of male $S$. linetaus and the strongest effect of extracts was observed in the first 36 hours of the experiment. The high values of the palatability index (particularly for the females) with relatively low absolute deterrence index, indicate limited possibilities of the use of aqueous extracts from fennel seeds for the protection against the feeding of the beetles from the genus Sitona.
\end{abstract}

Keywords: Sitona lineatus L., biological control, Foeniculum vulgare Mill., plant extracts

\section{INTRODUCTION}

Nowadays a great number of plant protection products exists. Chemical protection products are still most common in modern agriculture. Food manufacturers focus their actions to maximize production. However, the quality and nutritional value of thus obtained food may be decreased.

The use of plant extracts constitutes one of these crop protection methods, which are natural and safe for human health. Their action is often very efficient, does not exhibit phytotoxic effect on plants and does not contribute to the accumulation of harmful substances in plants and soil. Moreover, natural plant protection products do not lead to degradation of the natural environment.

Fennel (Foeniculum vulgare Mill.) is a vegetable in the Apiaceae family. The seeds, contained in the schizocarp and referred to as mericarps, are characterized by a high content of health promoting essential oils, also responsible for the strong aroma of the plant. The bulb-like stem base of fennel has a high nutritional value and constitutes the source of vitamins and mineral salts and an intensive essential oil [Janas 2013]. Fennel is widely used, from the food industry to the pharmaceutical industry. Fennel seeds are primarily used in phytotherapy [Kania et al. 2014]. Fennel is also a recognized phytosanitary plant. Usual$1 \mathrm{y}$, it is used for crop protection against numerous diseases. The study of Gleń and Boligłowa [2012] evaluated the effect of aqueous extracts from fennel on the linear growth of the phytopathogenic fungi Fusarium which inhabit broad bean seeds. The fungistatic effect of fennel extracts for F. culmorum was demonstrated in as much as $40-79 \%$. A study on the use of fennel extracts in the aspect of natural plant protection 
against pests [Błażejewska and Cieślińska 1996, Błażejewska and Wyrostkiewicz 1998, Wawrzyniak and Błażejewska 2001] was conducted and high efficiency of combating and decreasing activity of storage pests was obtained (i.e. wheat weevil and rice weevil).

Pea leaf weevil (Sitona lineatus L.) is one of the most important pests of Fabaceae plants in Poland [Strażyński 2013]. The half circle areas of pest feeding on leaves constitute the signs of beetle presence. On the other hand, pea leaf weevil larvae cause damage and necrobiosis of root nodules. An efficient protection against this crop pest primarily consists in chemical treatments [Gospodarek et al. 2012, Borowiecki 2006, Borowiecki and Ksiezak 2001, Borowiecki et al. 2004]. Unfortunately, this mode of plant protection is not allowed in organic farming [Kuś and Jończyk 2009], thus an attempt was made to examine natural methods of protection of broad bean against pea leaf weevil in the form of aqueous extracts from fennel seeds.

The objective of the study was to examine the effect of aqueous extracts from fennel (Foeniculum vulgare Mill.) seeds at 2\%, 5\%, 10\% and 20\% concentrations on the feeding of peal leaf weevil (Sitona lineatus L.) on broad bean (Vicia faba L.).

\section{MATERIALS AND METHODS}

Fresh leaves of broad bean of the Bartek cultivar were used in the laboratory experiment, collected from the same level of the stem below the apex in order to eliminate the effect of leaf age on the intensity of the pest feeding. The obtained plant material was treated with aqueous extracts from the fennel seeds. $2 \mathrm{~g}, 5 \mathrm{~g}, 10 \mathrm{~g}$ and $20 \mathrm{~g}$ of Foeniculum vulgare seeds was weighed (conventionally assumed as $2 \%, 5 \%, 10 \%$ and $20 \%$ concentrations) and then $100 \mathrm{ml}$ of cold redistilled water was added [Wawrzyniak and DębekJankowska 2010]. Extracts were stored for 24 hours in darkness in room temperature. Then, the obtained solutions were filtered through filter papers and were immediately used for the conduct of the experiment. The broad bean leaves were immersed for 3 seconds in the appropriate extract or in redistilled water (control) and then dried in room temperature, and then placed on Petri dishes lined with moist filter paper. Then, 1 pea leaf weevil beetle were placed in each Petri dish. The experiment was conducted in 6 replications, separately for females and males. During the experiment, filter paper was moistened in the dishes in order to prevent leaf drying and in 12 hour intervals, ninefold, measured area of broad bean leaves, eaten by pea leaf weevil beetle.

After conclusion of the conducted observations, the following values were calculated:

- palatability index - as the ratio of the percentage loss of the leaf blade in various combinations to the percentage loss of the leaf blade in the control,

- absolute deterrence index, which included the relationship between the area of leaf consumed by Sitona spp. in the analyzed objects and the area of leaf consumed in the control: Adi $=[(\mathrm{K}-\mathrm{T}):(\mathrm{K}+\mathrm{T})] \cdot 100$

where:

$K$ - the average area of leaf consumed by the pest in the control $\left[\mathrm{mm}^{2}\right]$,

$T$ - the average area of leaf consumed by the pest in the analyzed object $\left[\mathrm{mm}^{2}\right]$ [Kiełczewski et al. 1979].

The obtained results were subjected to analysis by STATISTICA 10.0 software. The significance of differences between the means were tested by univariate analysis of variance, and the means were differentiated by Fisher's LSD test at $\alpha=0.05$.

\section{RESULTS}

The conducted study has demonstrated that aqueous extract from fennel seeds had a very little impact on the feeding of $S$. lineatus females (Fig. 1, Table 1). During the entire period of conducted observations, the effect of this extract was not statistically significant.

Contrary to females, fennel seed extracts significantly limited the feeding of pea leaf weevil males at all dates of observation (Fig. 2, Table 2). At 24th and 36th hour, the effect of extracts was further differentiated - the extract with $2 \%$ concentration was characterized by lower efficiency than $10 \%$ and $20 \%$ extracts. In this initial period of feeding, the efficiency of extract increased with its concentration, however, starting from the 48 hour of the experiment till its ending, the significance of differences in the effect of individual extracts was not differentiated.

All used extracts from fennel seeds were characterized by inhibitory effect for female and male feeding on broad bean leaves, which is demonstrated by positive values of the absolute de- 


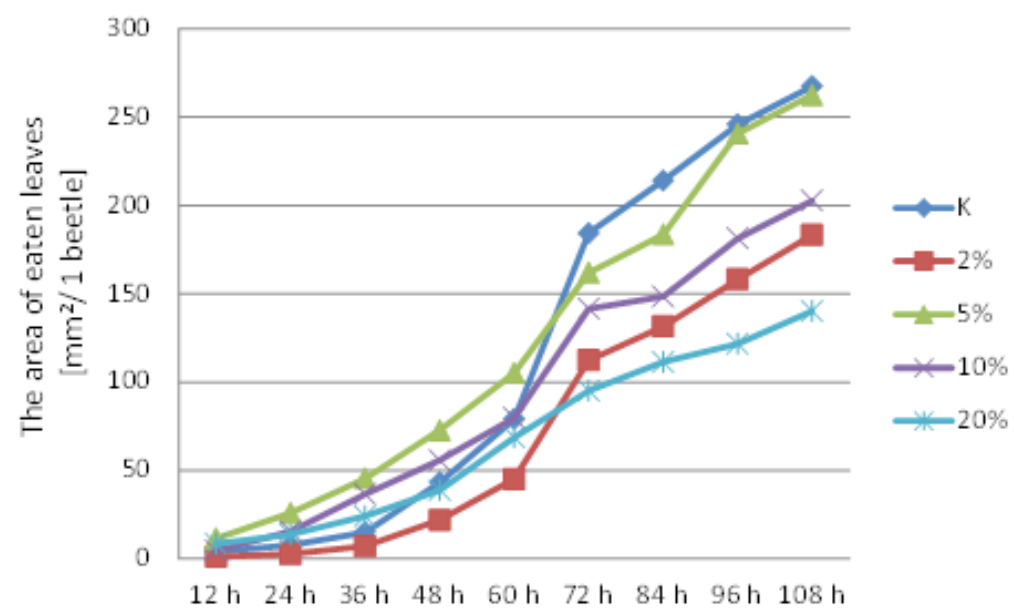

Fig. 1. The effect of extracts from seeds of Foeniculum vulgare Mill. at concentrations 2\%, 5\%, 10\% and 20\% on the area of feeding on the broad bean leaves caused by the female of Sitona lineatus $\mathrm{L} .\left[\mathrm{mm}^{2}\right]$. $\mathrm{K}-$ control.

Table 1. The results of the statistical analysis of the course of feeding of the female of Sitona lineatus on the broad bean leaves after application of aqueous extract from fennel seeds. Explanation as in Fig.1.

\begin{tabular}{|c|c|c|c|c|c|c|c|c|c|}
\hline Treatments & $12 \mathrm{~h}$ & $24 \mathrm{~h}$ & $36 \mathrm{~h}$ & $48 \mathrm{~h}$ & $60 \mathrm{~h}$ & $72 \mathrm{~h}$ & $84 \mathrm{~h}$ & $96 \mathrm{~h}$ & $108 \mathrm{~h}$ \\
\hline $\mathrm{K}$ & $\mathrm{ab}$ & $\mathrm{a}$ & $\mathrm{ab}$ & $\mathrm{a}$ & $\mathrm{a}$ & $\mathrm{a}$ & $\mathrm{a}$ & $\mathrm{a}$ & $\mathrm{a}$ \\
\hline $2 \%$ & $\mathrm{a}$ & $\mathrm{a}$ & $\mathrm{a}$ & $\mathrm{a}$ & $\mathrm{a}$ & $\mathrm{a}$ & $\mathrm{a}$ & $\mathrm{a}$ & $\mathrm{a}$ \\
\hline $5 \%$ & $\mathrm{c}$ & $\mathrm{b}$ & $\mathrm{b}$ & $\mathrm{a}$ & $\mathrm{a}$ & $\mathrm{a}$ & $\mathrm{a}$ & $\mathrm{a}$ & $\mathrm{a}$ \\
\hline $10 \%$ & $\mathrm{ab}$ & $\mathrm{ab}$ & $\mathrm{ab}$ & $\mathrm{a}$ & $\mathrm{a}$ & $\mathrm{a}$ & $\mathrm{a}$ & $\mathrm{a}$ & $\mathrm{a}$ \\
\hline $20 \%$ & $\mathrm{bc}$ & $\mathrm{ab}$ & $\mathrm{ab}$ & $\mathrm{a}$ & $\mathrm{a}$ & $\mathrm{a}$ & $\mathrm{a}$ & $\mathrm{a}$ & $\mathrm{a}$ \\
\hline
\end{tabular}

* The same letters in columns mean that means do not differ significantly at $\alpha=0.05$.

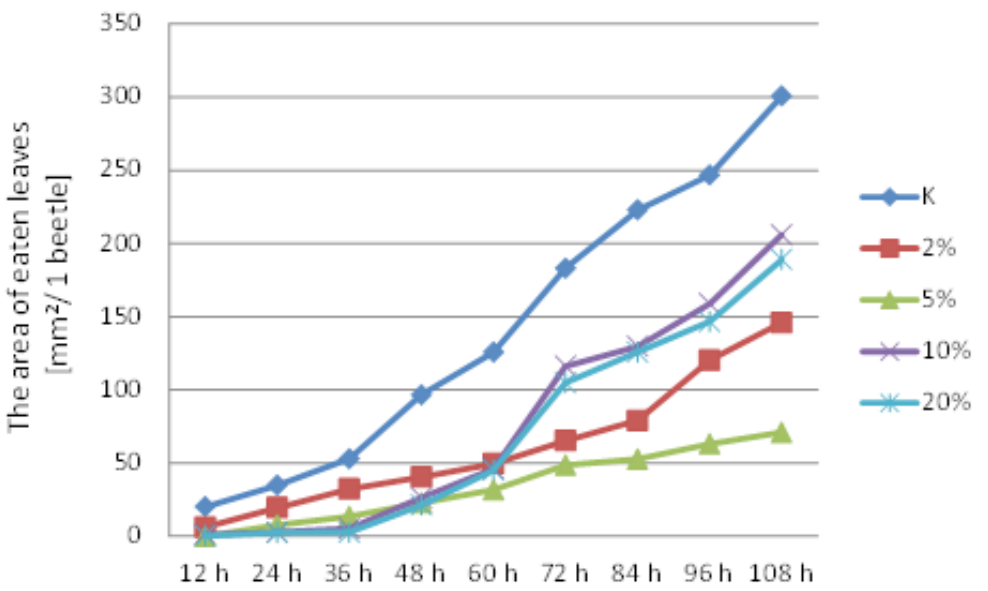

Fig. 2. The effect of extracts from seeds of Foeniculum vulgare Mill. at concentrations 2\%, 5\%, 10\% and 20\% on the area of feeding on the broad bean leaves caused by the male of Sitona lineatus L. [mm ${ }^{2}$. K - control.

Table 2. The results of the statistical analysis of the course of feeding of the male of Sitona lineatus on the broad bean leaves after application of aqueous extract from fennel seeds. Explanation as in Fig.1.

\begin{tabular}{|c|c|c|c|c|c|c|c|c|c|}
\hline Treatments & $12 \mathrm{~h}$ & $24 \mathrm{~h}$ & $36 \mathrm{~h}$ & $48 \mathrm{~h}$ & $60 \mathrm{~h}$ & $72 \mathrm{~h}$ & $84 \mathrm{~h}$ & $96 \mathrm{~h}$ & $108 \mathrm{~h}$ \\
\hline $\mathrm{K}$ & $\mathrm{b}$ & $\mathrm{c}$ & $\mathrm{c}$ & $\mathrm{b}$ & $\mathrm{b}$ & $\mathrm{b}$ & $\mathrm{b}$ & $\mathrm{b}$ & $\mathrm{b}$ \\
\hline $2 \%$ & $\mathrm{a}$ & $\mathrm{b}$ & $\mathrm{bc}$ & $\mathrm{a}$ & $\mathrm{a}$ & $\mathrm{a}$ & $\mathrm{a}$ & $\mathrm{a}$ & $\mathrm{a}$ \\
\hline $5 \%$ & $\mathrm{a}$ & $\mathrm{ab}$ & $\mathrm{ab}$ & $\mathrm{a}$ & $\mathrm{a}$ & $\mathrm{a}$ & $\mathrm{a}$ & $\mathrm{a}$ & $\mathrm{a}$ \\
\hline $10 \%$ & $\mathrm{a}$ & $\mathrm{a}$ & $\mathrm{a}$ & $\mathrm{a}$ & $\mathrm{a}$ & $\mathrm{a}$ & $\mathrm{a}$ & $\mathrm{a}$ & $\mathrm{a}$ \\
\hline $20 \%$ & $\mathrm{a}$ & $\mathrm{a}$ & $\mathrm{a}$ & $\mathrm{a}$ & $\mathrm{a}$ & $\mathrm{a}$ & $\mathrm{a}$ & $\mathrm{a}$ & $\mathrm{a}$ \\
\hline
\end{tabular}

* The same letters in columns mean that means do not differ significantly at $\alpha=0.05$. 
terrence index (Fig. 3). No relationship between the high concentration of extract and efficiency of beetle feeding inhibition was determined. The absolute deterrence index demonstrated its highest value for the aqueous extract from fennel seeds at $5 \%$ concentration towards males. On the other hand, the same concentration level turned out to be of little efficiency for the feeding of pea leaf weevil females, where the index value was at its lowest level.

The value of palatability index in the case of females was highest for the $5 \%$ fennel seed aqueous extract. A reversed relationship was observed for the pea leaf weevil males, in which the 5\% extract resulted in the lowest value of the palatability index (Fig. 4). The remaining concentrations, except for the $20 \%$ concentration, exhibited higher values for females than males. Only in the case of the strongest fennel seed extract with $20 \%$ concentration, similar values for both males and females were observed.

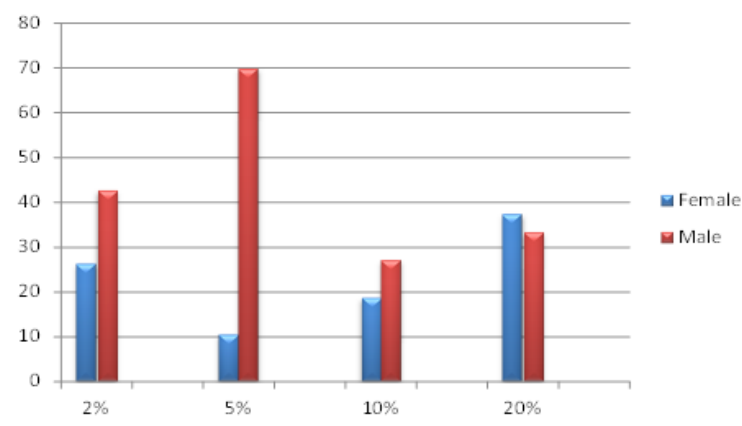

Fig. 3. Absolute deterrence index of extracts from seeds of $F$. vulgare in concentrations $2 \%, 5 \%, 10 \%$ and $20 \%$, for female and male of Sitona lineatus, calculated according to the formula: Adi $=[(\mathrm{K}-\mathrm{T}):(\mathrm{K}+\mathrm{T})] \cdot 100$, where: $\mathrm{K}$ - the average area of leaf consumed by the pest in the control $\left[\mathrm{mm}^{2}\right], \mathrm{T}-$ the average area of leaf consumed by the pest in the analyzed object $\left[\mathrm{mm}^{2}\right]$

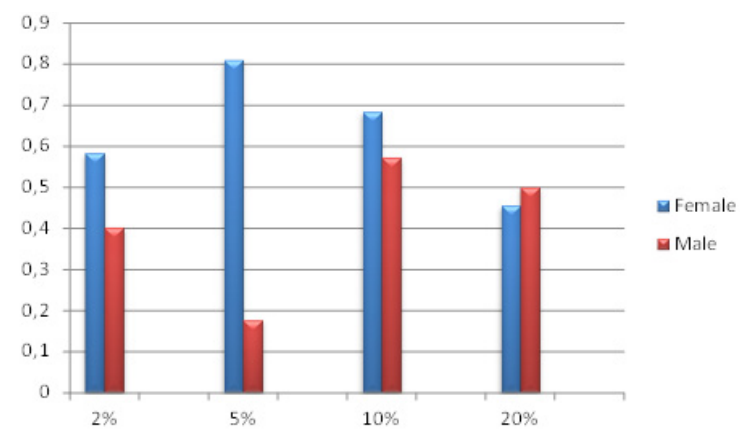

Fig. 4. Palatability index after applying of extracts from seeds of $F$. vulgare at concentrations $2 \%, 5 \%$, $10 \%$ and $20 \%$, calculated as ratio of the percentage loss of leaf blade in analysed objects to the percentage loss of leaf blade in control

\section{DISCUSSION}

The conducted experiment demonstrated, that aqueous fennel seed extracts exhibited diversified effect towards females and males of pea leaf weevil. The restricting effect of extracts was observed only for males. The relatively low effect towards females may resulted from their increased food requirements during the breeding period, as on average the males consumed approximately $50 \mathrm{mg}$ less food than the females.

The available literature provides only few studies on the use of fennel seed extracts in plant protection against pests. A toxic effect of alcohol extracts from F. vulgare schizocarps towards Attagenus unicolor japonicus larvae (Coleoptera: Dermestidae) was observed. They caused $67 \%$ and $100 \%$ mortality at respective doses of 2.6 $\mathrm{mg} / \mathrm{cm}^{2}$ and $5.2 \mathrm{mg} / \mathrm{cm}^{2}$ of leaf [Han et al. 2006]. More studies on the use of essential oils can be found. Strong insecticidal properties of fennel essential oils towards wheat weevil (Sitophilus granarius) and rice weevil (Sitophilus oryzae) were observed already in the 24 hours of experiment [Ebadollahi 2011]. Similarly high toxicity of the plant oil was exhibited towards the mites Tyrophagus putrescentiae. The analysis of the essential oil composition demonstrated that its main components, i.e. carvone and naphthalene, are responsible for this effect, [Lee et al. 2006]. A study was also conducted on the effect of $F$. vulgare essential oils on the mosquito Culex pipiens L. larvae and pupae. A concentration of $40 \mathrm{mg} / \mathrm{l}$ caused approx. $50 \%$ mortality in the L2 larvae already at the 2 hour of observation, whereas $60 \mathrm{mg} / 1$ concentration after a 4-hour exposition of L4 larvae to the effect of the oil brought $90 \%$ mortality. $100 \%$ of pupae mortality was obtained only after 24 hours of observation using the $200 \mathrm{mg} / \mathrm{l}$ dose [Zoubiri et al. 2014]. On the other hand, for larvae of Aedes albopictus (Culiciadae), another mosquito species, a solution of $300 \mathrm{ppm}$ oil and $250 \mathrm{ml}$ mineral water with $0.1 \%$ Tween 80 after 24 hours resulted in $98.3-100 \%$ mortality of these insects [Conti et al. 2010].

The available literature lacks data on the effect of extracts or essential oils from fennel in combating weevil beetles. The only data on these pests refer to the use of fennel as a component of mixed cropping. Fennel, as a companion plant in the broad bean cultivation did not have a clear effect on the infestation of the host plant by pea leaf weevil and the level of root nodule damage by Sitona spp. larvae [Gospodarek et al. 2011]. 
Significant differences between individual study seasons were demonstrated, which may result from different weather conditions.

\section{CONCLUSIONS}

1. No significant, limiting effect of fennel seed aqueous extracts on the feeding of the pea leaf weevil females was determined.

2. Contrary, all of the used fennel extracts had inhibitory effect on the feeding of male $S$. linetaus. The strongest effect of extracts was observed in the first 36 hours of the experiment.

3. The high values of the palatability index (particularly for the females) with relatively low absolute deterrence index, indicate limited possibilities of the use of aqueous extracts from fennel seeds for the protection against the feeding of the beetles from the genus Sitona.

\section{Acknowledgements}

The study implemented within the framework of the specific grant for the conduct of scientific study or development works and the associated tasks, contributing to the development of young scientists and participants of doctoral studies of the Agricultural University, financed by means of competition in 2015- topic no. 4171 and by the Ministry of Science and Higher Education of the Republic of Poland

\section{REFERENCES}

1. Błażejewska A. 1969. Płodność wołka zbożowego (Calandra granaria L.) hodowanego na ziarnach pszenicy traktowanej chlorkiem chlorocholiny (CCC) Rocz. Nauk R01. 95: 393-399.

2. Błażejewska A., Cieślińska A. 1996. Wpływ suszu z kolendry siewnej i z owoców kopru włoskiego na rozwój i płodność wołka ryżowego. Prog. Plant Protection/Post. Ochr. Roślin 36 (2): 47-50.

3. Borowiecki J. 2006. Czynniki ograniczające plonowanie grochu (Pisum sativum L.). Postępy Nauk Rolniczych. 53(1). 81-87.

4. Borowiecki J., Ksiezak J. 2001. Stan badan nad oprzedzikiem pregowanym (Sitona lineatus L.) - szkodnikiem grochu. Postępy Nauk Rolniczych. 48(3). 99-110.

5. Borowiecki J., Ksiezak J., Bournoville R., Lerin J. 2004. Wpływ żerowania oprzędzików na ro- zwój i plonowanie grochu. Pamiętnik Puławski. 137. 5-14.

6. Conti B., Canale A., Bertoli A., Gozzini F., Pistelli L. 2010. Essential oil composition and larvicidal activity of six Mediterranean aromatic plants against the mosquito Aedes albopictus (Diptera: Culicidae). Parasitology Research. 107(6). 1455-1461.

7. Dutka A. 2013. Application of essential oils in plant protection against pest insects - paper review. Progress In Plant Protection. 53(1). 36-42.

8. Ebadollahi, A. 2011. Susceptibility of Two Sitophilus species (Coleoptera: Curculionidae) to Essential Oils from Foeniculum vulgare and Satureja hortensis. Ecologia Balkanica. 3(2). 1-8.

9. Farooq A. Muhammad A., Abdullah Ijaz H., Muhammad S. 2009. Antioxidant and antimicrobial activities of essential oil and extracts of fennel (Foeniculum vulgare Mill.) seeds from Pakistan. Flavour and Fragrance Journal. 24(4). 170-176.

10. Gleń K., Boligłowa E. 2012. Oddziaływanie wyciągów z roślin zielarskich na dominujące gatunki grzybów zasiedlających nasiona bobu. Journal of Research and Applications in Agricultural Engineering. 57(3). 98-103.

11. Gospodarek J., Boligłowa E., Gleń K. 2011. Porównanie niechemicznego i chemicznego sposobu ochrony bobu przed oprzędzikami (Sitona spp.). Progress In Plant Protection/Postępy W Ochronie Roślin 52(1). 26-30.

12. Gospodarek J., Gleń K., Boligłowa E. 2011. Wpływ uprawy współrzędnej bobu odmiany Windsor Biały z wybranymi ziołami na dynamikę żerowania oprzędzików (Sitona sp.). Journal of Research and Applications in Agricultural Engineering. 56(3). 117-121.

13. Han M.K., Kim S.I. Ahn Y. J. 2006. Insecticidal and antifeedant activities of medicinal plant extracts against Attagenus unicolor japonicus (Coleoptera: Dermestidae). Journal of Stored Products Research. 42(1). 15-22.

14. Janas R. 2013. Evaluation of possibility of the seed health status improving of dill and fennel grown in organic systems. Journal of Research and Applications in Agricultural Engineering, 58(3), 226-228.

15. Kania M., Baraniak J., Grys A. 2014. St. Hildegard of Bingen - phytotherapy and dietary recommendations. Part 2. Borgis - Postępy Fitoterapii 2/2014, 104-109.

16. Kiełczewski M., Drożdż B., Nawrot J. 1978. Badania nad repelentami pokarmowymi trojszyka ulca (Tribolium confusum Duv.). Materiały 19 Sesji Naukowej Instytutu Ochrony Roślin, cz.1., 367-376.

17. Kuś J., Jończyk K. 2009. Rozwój rolnictwa eko- 
logicznego w Polsce. Journal of Research and Applications in Agricultural Engineering. 54(3). 178-182.

18. Lee C.H., Sung B.K., Lee H.S. 2006. Acaricidal activity of fennel seed oils and their main components against Tyrophagus putrescentiae, a storedfood mite. Journal of Stored Products Research. 42(1). 8-14.

19. Oktay M., Gülçin I., Küfrevioğlu O.I. 2003. Determination of in vitro antioxidant activity of fennel (Foeniculum vulgare) seed extracts. LWT - Food Science and Technology. 36(2). 263-271.

20. Strażyński P. 2013. The dynamics of the occurrence of pea leaf weevil (Sitona lineatus L.) on pea and faba bean crops on selected localities in Wiel- kopolska. Progress In Plant Protection/Postępy W Ochronie Roślin 53(4). 709-712.

21. Wawrzyniak M., Błażejewska A. 2001. Estimation of activity of powdered fruits of common fennel (Foeniculum capillaceum Gilib.) on the fecundity of Sirophilus oryzae L. J. Plant Prot. Res. 41: 329-332.

22. Wawrzyniak M., Dębek-Jankowska A. 2010. Oddziaływanie wybranych wodnych wyciągów roślinnych na wołka zbożowego. Prog. Plant Prot., 50(1), 398-401.

23. Zoubiri S., Baaliouamer A., Seba N., Chamouni N. 2014. Chemical composition and larvicidal activity of AlgerianFoeniculum vulgare seed essential oil. Arabian Journal of Chemistry. 7(4). 480-485.

Pracę dofinansowano ze środków Wojewódzkiego Funduszu Ochrony Środowiska i Gospodarki Wodnej w Lublinie. 